Dr Milorad Radetić,

dipl. inž.

Vojnotehnički institut,

Beograd

\section{ODREĐIVANJE OSNOVNIH PARAMETARA PRI UBRZAVANJU BRZOHODNIH GUSENIČNIH VOZILA}

UDC: $623.438 .3-58$

Rezime:

Mogućnost ubrzavanja vozila ima poseban značaj kod brzohodnih guseničnih vozila specijalne namene, posebno kada su u pitanju borbena vozila. Ova mogućnost karakteriše dinamičke karakteristike vozila i ima poseban značaj za preživljavanje vozila na bojištu. Kod realizovanih vozila određivanje osnovnih parametra koji karakterišu ubrzavanje vozila uglavnom se vrši eksperimentalno, a kod vozila u razvoju proračunski. Pri proračunu se javljaju određeni problemi jer se ne mogu uzeti u obzir sve veličine koje na njih utiču. U ovom radu prikazan je postupak pomoću kojeg se na jednostavan način mogu odrediti ovi parametri računskim putem, pri čemu se dobijaju vrednosti približne realnim.

Ključne reči: gusenično vozilo, ubrzavanje, ubrzanje, vreme, put.

\title{
DETERMINATION OF BASIC PARAMETERS DURING HIGH-SPEED TRACKED VEHICLE ACCELERATION
}

Summary:

The possibility of a vehicle to accelerate is very important for special-purpose highspeed tracked vehicles, especially for combat vehicles. It determines vehicle dynamic characteristics and has an important role for vehicle survivability. The determination of basic vehicle acceleration parameters is mostly carried out experimentally on realized vehicles but for vehicles in development it is determined by calculation. Some problems are present during the calculation because it is not possible to take into account all influencing parameters. The procedure for an easy calculation of these parameters is given in this paper. The values of the parameters obtained by this procedure are close to real values.

Key words: tracked vehicle, acceleration process, acceleration, time, distance.

\section{Uvod}

Kretanje brzohodnih guseničnih vozila specijalne namene, posebno borbenih, karakterišu česte promene brzine, što određuju uslovi eksploatacije. Ako u borbenim uslovima ova vozila za kraće vreme postignu veću brzinu, koju mogu ostvariti zahvaljujući rezervi specifične snage, ona će biti manje izložena vatri protivnika, što povećava mogućnost preživljavanja na bojištu.
Pri marševskom kretanju koje se, uglavnom, ostvaruje kretanjem u koloni, vreme i pređeni put pri ubrzavanju i usporavanju svakog vozila utiču na razvučenost kolone i srednju brzinu kretanja. Kada se vozila kreću na rastojanju jedno od drugog, vozač svakog vozila, pod uslovom da vozilo ima efikasan kočioni sistem, nastoji da ostvari visoke brzine kretanja, što se manifestuje visokim prosečnim brzinama kretanja $\mathrm{i}$ smanjenjem rastojanja između vozila. 
Može se zaključiti da je jedna od najvažnijih karakteristika ovih vozila mogućnost brze promene brzine kretanja, odnosno postizanje dobrog ubrzavanja vozila, što je sigurno značajnije od maksimalne brzine koju vozilo može da ostvari.

Za ocenu ove karakteristike merodavni su sledeći parametri: ubrzanje, vreme ubrzavanja i pređeni put pri ubrzavanju.

Navedeni parametri se kod realizovanih vozila određuju na osnovu dijagrama za čiju se izradu elementi najčešće dobijaju eksperimentalnim putem, ispitivanjem vozila u terenskim uslovima, dok se za vozila koja se nalaze $u$ fazi razvoja određuju računskim putem, na osnovu čega se crta dijagram.

\section{Postupak odredivanja parametara}

Da bi se pojednostavio postupak proračuna pretpostaviće se da je obrtni moment motora konstantna veličina $\mathrm{i}$ da predstavlja srednju vrednost momenata radnog područja motora. Pod radnim područjem podrazumeva se područje između radnih tačaka koje odgovaraju maksimalnom momentu i momentu pri nominalnoj snazi, kada motor radi na spoljnoj brzinskoj karakteristici.

Srednja vrednost obrtnog momenta, u ovom slučaju, određuje se prema izrazu:

$$
M_{S}=\frac{1+K_{d}}{2} M_{N}
$$

gde je:

$K_{d}$ - koeficijent elastičnosti motora:

$$
K_{d}=\frac{M_{\max }}{M_{N}}
$$

$M_{\max }$ - maksimalni obrtni moment motora,
$M_{N}$ - obrtni moment motora pri maksimalnoj snazi.

U slučaju jednolikog kretanja, sila vuče, koju obezbeđuje motor, služi za savlađivanje otpora kretanju vozila. Ako je sila vuče koju obezbeđuje motor veća ili manja od potrebne da bi se savladali otpori kretanju, tada se vozilo kreće ubrzanim, odnosno usporenim kretanjem. U prvom slučaju rezerva snage omogućuje ubrzavanje vozila, a u drugom se na račun akumulirane kinetičke energije povećava pogonska sila do potrebne vrednosti.

Za analizu promenljivog kretanja biće primenjen Dalamberov princip po kojem se sile inercije koje deluju na telo uravnotežavaju drugim spoljašnjim silama. Primenjeno na vozilo to znači da bi inercijalna sila $\left(F_{o j}\right)$ bila u ravnoteži sa pogonskom silom $\left(F_{M}\right)$ i silom otpora kretanja $\left(R_{f}\right)$. Ako se saberu sile koje deluju na vozilo duž uzdužne ose (slika 1) dobija se:

$F_{M}=R_{f}+F_{i o}$

Sila vuče, koju obezbeđuje motor na pogonskim točkovima, može se odrediti prema izrazu:

$F_{M}=\frac{P_{e} \cdot \eta}{V_{o}}$

Srednja vrednost ove sile $\left(F_{M S}\right)$ može se odrediti prema sledećim izrazima:

$F_{M}=\frac{K_{d}+1}{2} \frac{\eta \cdot P_{e}}{V_{p t}}$

odnosno:

$F_{M s}=\frac{M_{s} \eta}{r_{p t}}$ 


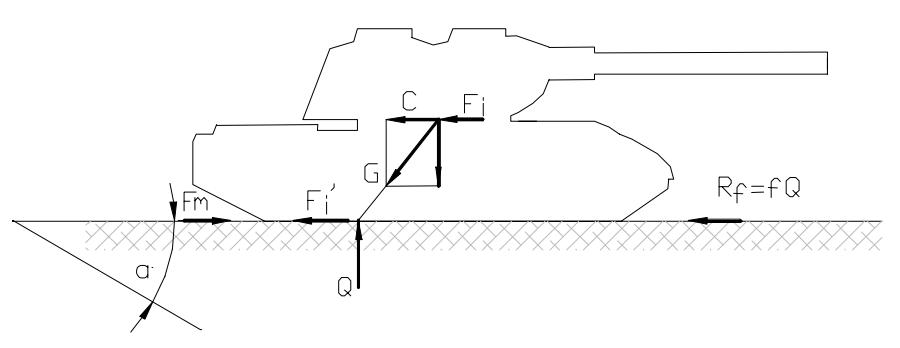

Sl. 1 - Sile koje deluju na gusenično vozilo duž uzdužne ose

gde je:

$\eta$ - ukupni stepen korisnosti prenosa snage preko kinematskog lanca od motora do pogonskih točkova i hodnog uređaja, uključujući i gusenice,

$P_{e}$ - efektivna snaga koja ulazi u transmisiju,

$V_{o}$ - brzina kretanja vozila,

$V_{p t}$ - obimna brzina pogonskih točkova.

Može se usvojiti, sa dovoljnom tačnošću, da je $V_{o}=V_{p t}$,

$\alpha$-ugao uspona.

Sila otpora kretanju određuje se prema izrazu:

$R_{f}=f_{0} Q$

gde je:

$f_{0}$ - ukupni koeficijent otpora kretanju:

$f_{0}=f \cos \alpha+\sin \alpha$

$f$ - koeficijent otpora kretanju.

Kada se vozilo nalazi na horizontalnoj podlozi, onda je $Q=G$ i $f_{0}=f$, tako da izraz za silu otpora glasi:

$$
R_{f}=G f
$$

Sila inercije određuje se kao zbir inercijalnih sila vozila $\left(F_{j}\right)$ i inercijalnih sila elemenata transmisije i hodnog uredaja redukovanih na gusenicu $\left(F_{i}{ }^{\prime}\right)$ :

$F_{i o}=F_{i}+F_{i}^{\prime}=m \delta a$ gde je:

$m$ - masa vozila,

$\delta$ - koeficijent uslovnog priraštaja masa rotirajućih delova,

$a$ - ubrzanje vozila, koje se može izraziti kao promena brzine u jedinici vremena:

$a=\frac{d v}{d t}$

$v$ - brzina kretanja vozila,

$t$ - vreme kretanja.

Određivanje koeficijenta $\delta$ računskim putem veoma je složeno jer treba uzeti u obzir masu i obrtne momente svih rotirajućih i pokretnih delova u kinematskom lancu od motora do pogonskih točkova, uključujući hodni uređaj i gusenice. Međutim, postoje empirijski izrazi pomoću kojih se sa prihvatljivom greškom može odrediti ovaj koeficijent. Za transmisiju sa stepenastom promenom prenosnog odnosa:

- prema [1]

$\delta=1,2+0,002 i_{0}^{2}$

- prema [2]

$\delta=1,2+0,0015 i_{0}^{2}$

gde je $i_{0}$ prenosni odnos transmisije od motora do pogonskih točkova. 
U slučaju prekida kinematske veze između motora i transmisije umesto $\delta$ uzima se koeficijent $\delta^{\prime}$, čija se vrednost prema [2] može usvojiti $\delta^{\prime}=1,2$. Ako se u (2) uvrste izrazi za $F_{M s}, R_{f}$ i $F_{i 0}$ dolazi se do izraza za ubrzanje vozila:

$$
a=\frac{d v}{d t}=\left(D-f_{0}\right) \frac{g}{\delta}
$$

gde je $D$ dinamički faktor vozila $(D=$ $\left.F_{M s} / G\right)$.

Pošto se veličine sa desne strane izraza (9) mogu uzeti kao konstantne, jer je na početku usvojeno da je obrtni moment motora konstantan, tako će i ubrzanje a, odnosno $d v / d t$, biti konstantno. Prema tome, kretanje se posmatra kao jednakoubrzano.

Polazeći od izraza za brzinu kod jednakoubrzanog kretanja:

$$
V=V_{0}+a t
$$

vreme ubrzavanja $\mathrm{u} i$-tom stepenu prenosa može se odrediti prema izrazu:

$t_{i}=\frac{V_{2 i}-V_{1 i}}{\left(\frac{d V}{d t}\right)_{i}}$

gde je:

$V_{l i}$ - brzina pri kojoj vozilo počinje da se ubrzava u i-tom stepenu prenosa, $V_{2 i}$ - brzina do koje se vozilo ubrzava u $i$-tom stepenu prenosa.

Da bi se nacrtao dijagram ubrzavanja potrebno je imati dijagram vuče za vozilo sa koga bi se uzeli podaci za maksimalne brzine $\mathrm{u}$ pojedinim stepenima prenosa, ili da se iste izračunaju. Pri prelasku iz jednog stepena prenosa $\mathrm{u}$ drugi dolazi do pada brzine $(\Delta V)$ za vreme $\Delta t$ koje je potrebno za prelazak iz jednog stepena prenosa u drugi.

Pri promeni stepena prenosa motor je odvojen od transmisije i vozilo se kreće usled inercije. Tada je $F_{M}=0$, a umesto koeficijenta $\delta$ uvršćuje se koeficijent $\delta^{\prime}$.

Ako se u izrazu (9) primeni da je $F_{M}$ $=0$, odnosno $D=0$, dobija se da je:

$-\frac{d V}{d t}=\left(\frac{d V}{d t}\right)^{*}=\frac{f_{0} g}{\delta^{\prime}}$

Izraz (11) služi da se proračuna koliko je usporenje vozila koje je u narednim izrazima označeno kao $(d V / d t)^{*}$.

Kada je poznato usporenje vozila može se odrediti pad brzine pri promeni stepena prenosa:

$\Delta V=\left(\frac{d V}{d t}\right)_{i}^{*} \Delta t_{i}$

gde indeks i označava stepen prenosa, a $\Delta t$ vreme potrebno da se izvrši promena stepena prenosa.

Prema [1, 2 i 3$] \Delta t=2 \div 3 s$, kada se promena stepena prenosa vrši pomoću zupčaste spojnice, $\Delta t=1 \div 1,5 \mathrm{~s}$ za promenu stepena prenosa pomoću sinhronizera, $\Delta t=0,5 \div 1 \mathrm{~s}$ za planetarne prenosnike kod kojih se promena stepena prenosa vrši pomoću frikcionih sklopova i za planetarne prenosnike sa automatskom promenom stepena prenosa $\Delta t=0,2 \div 0,5 \mathrm{~s}$.

Kada se vozilo kreće i-tim stepenom prenosa $\mathrm{u}$ trenutku prelaska na sledeći stepen prenosa $(i+1)$, brzina vozila je $V_{1(i+1)}$. Ova brzina je jednaka zbiru maksimalne brzine koju je vozilo ostvarilo $u$ prethodnom stepenu prenosa $\left(V_{2 i}\right)$ i smanjenju brzine $\Delta V_{i}\left(\Delta V_{i}<0\right)$ : 


$$
V_{1(i+1)}=V_{2 i}+\left(\frac{d V}{d t}\right)^{*} \Delta t
$$

$\mathrm{Na}$ osnovu ovako određenih veličina može se nacrtati dijagram ubrzavanja vozila (slika 2), s tim što se na apscisu nanosi vreme, a na ordinatu brzina.

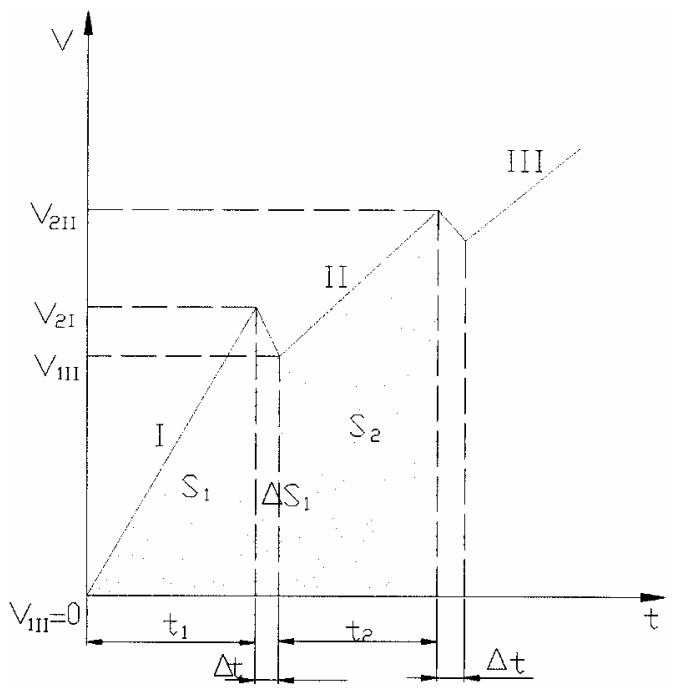

Sl. 2 - Dijagram ubrzavanja guseničnog vozila

Ukupno vreme ubrzavanja vozila određuje se prema izrazu:

$t_{u}=\sum_{1}^{n+1} t_{i}+n \Delta t$

gde je:

$t_{i}$ - vreme ubrzavanja u određenim stepenima prenosa, određena pomoću (10),

$n$-broj stepeni prenosa koji se uključuje.

$\mathrm{Na}$ osnovu ovog dijagrama može se odrediti put ubrzavanja, prema sledećem izrazu:

$$
S_{u}=\sum_{1}^{n+1} S_{i}+\sum_{1}^{n} \Delta S_{i}
$$

gde je:

$S_{i}$ - pređeni put u i-tom stepenu prenosa koji se određuje kao površina, koju čine linija ubrzavanja, apscise i ordinata, za dati stepen prenosa,

$\Delta S_{i}$ - put usporenja zbog promene stepena prenosa.

\section{Zaključak}

Jedna od značajnih dinamičkih karakteristika savremenih borbenih guseničnih vozila koja se u poslednje vreme posebno ističe je karakteristika ubrzavanja vozila, tj. mogućnost da vozilo pri kretanju ili iz stanja mirovanja za što kraće vreme postigne određenu brzinu.

Kod realizovanih vozila eksperimentalno se potvrđuju vrednosti parametara ubrzavanja sa kojima se ušlo u projekat, dok se kod novih vozila koja se nalaze u fazi projektovanja ovi parametri određuju proračunski uz određene pretpostavke. Za njihov proračun primenjuje se više metoda. Mada izloženi tok proračuna prilično verno opisuje ponašanje vozila u realnim uslovima, ipak treba obratiti posebnu pažnju na izbor vrednosti koeficijenata, kako bi što adekvatnije odgovarali uslovima za koje se vrši proračun.

\section{Literatura:}

[1] Zabrunikov, N. A.: Osnovi teorij transportnih guseničnih mašin, Mašinostroenie, Moskva, 1975.

[2] Antonov, A. S.: Guseničnie tjagači, Posebno izdanje, Moskva, 1959.

[3] Nikitin, A. O., Sergeev, L. V.: Teorij tanka, Izdanie Akademij, Moskva, 1962. 